\title{
New distributional and morphological data of two species of catsharks, genus Scyliorhinus Blainville, 1816 (Carcharhiniformes, Scyliorhinidae), from the western South Atlantic
}

\author{
Stephani M. Lopes ${ }^{1}$, Luciano G. Fischer ${ }^{1}$, Rodrigo C. Mazzoleni², Michael M. Mincarone ${ }^{1}$
}

1 Universidade Federal do Rio de Janeiro, Instituto de Biodiversidade e Sustentabilidade, CP 119331, Macaé, RJ, 27910-970, Brazil. 2 Universidade do Vale do Itajaí, Escola do Mar, Ciência e Tecnologia, Laboratório de Ecossistemas Aquáticos e Pesqueiros, Rua Uruguai, 458, Itajaí, SC, $88302-$ 901, Brazil.

Corresponding author: Luciano G. Fischer, luciano.fischer@gmail.com

\begin{abstract}
This study provides new distributional and morphological information for two recently described species of catsharks (Carcharhiniformes, Scyliorhinidae) from Brazil. Scyliorhinus cabofriensis Soares, Gomes \& Carvalho, 2016, originally described from off Cabo Frio, state of Rio de Janeiro (536 m depth) is recorded in deeper waters (647 m) off northern Rio de Janeiro, and Scyliorhinus ugoi Soares, Gadig \& Gomes, 2015, previously known from the Caribbean Sea to Rio de Janeiro (depth unknown), is reported off the state of Santa Catarina, southern Brazil, at 825 m. Morphometric data are provided for all the specimens examined.
\end{abstract}

\section{Keywords}

Brazil, new records, Scyliorhinus cabofriensis, Scyliorhinus ugoi.

Academic editor: Arturo Angulo | Received 8 October 2019 | Accepted 24 December 2019 | Published 10 January 2020

Citation: Lopes SM, Fischer LG, Mazzoleni RC, Mincarone MM (2020) New distributional and morphological data of two species of catsharks, genus Scyliorhinus Blainville, 1816 (Carcharhiniformes, Scyliorhinidae), from the western South Atlantic. Check List 16 (1): 47-52. https://doi. org/10.15560/16.1.47

\section{Introduction}

The Scyliorhinidae (Elasmobranchii, Carcharhiniformes), with 17 genera and approximately 160 species, is the most diverse family of sharks (Nelson et al. 2016; Soares and Carvalho 2019). The genus Scyliorhinus Blainville, 1816 comprises 16 valid species living from the intertidal zone to continental slopes, although the majority occurs in deep waters, usually below $200 \mathrm{~m}$ (Compagno 1984; Weigmann 2016; Soares and Carvalho 2019). Four valid species of Scyliorhinus have been reported in the western South Atlantic: Scyliorhinus boa (Goode \& Bean,
1896), known from the Caribbean Sea to northeastern Brazil (Rio Grande do Norte); Scyliorhinus haeckeli (Miranda Ribeiro, 1907), known from southern Bahia (Brazil) to northern Argentina; Scyliorhinus cabofriensis Soares, Gomes \& Carvalho, 2016, from Rio de Janeiro (Brazil); and Scyliorhinus ugoi Soares, Gadig \& Gomes, 2015, from the Caribbean Sea (Barbados) to Rio de Janeiro (Brazil) (Lins-Oliveira et al. 2015; Soares et al. 2015, 2016; Soares and Carvalho 2019). Scyliorhinus besnardi Springer \& Sadowsky 1970, traditionally recognized from the western South Atlantic, was recently synonymized with $S$. haeckeli by Soares et al. (2016). A fifth 
unnamed species of Scyliorhinus is believed to occur on the continental slopes off southern Brazil (Rincón-Filho et al. 2017).

The morphological and/or distributional information available for $S$. cabofriensis and $S$. ugoi are those mentioned in the original descriptions (Soares et al. 2015, 2016) and in a recent taxonomic review (Soares and Carvalho 2019), which were based on 23 and 26 specimens, respectively. The aim of our study is to present new records and range extensions of $S$. cabofriensis and S. ugoi based on the recent examination of specimens deposited in fish collections. Additional morphological data for both species are also provided.

\section{Methods}

Specimens are deposited in Fish Collection of the Instituto de Biodiversidade e Sustentabilidade, Universidade Federal do Rio de Janeiro (NPM; Macaé, Brazil) and Laboratório de Ecossistemas Aquáticos e Pesqueiros, Universidade do Vale do Itajaí (LEAP; Itajaí, Brazil). Specimens were identified according to Soares et al. (2015, 2016) and Soares and Carvalho (2019). Measurements (Table 1) were taken with calipers to the nearest $0.1 \mathrm{~mm}$, according to Compagno (2001). Radiographs of specimens were taken using a Faxitron LX-60 to aid vertebrae counts.

\section{Results}

Scyliorhinus cabofriensis Soares, Gomes \& Carvalho, 2016

Figures 1-3, Table 1

New records. BRAZIL 1 1 (408 $\mathrm{mm} \mathrm{TL})$; state of Rio de Janeiro, off Cabo de São Tomé; $22^{\circ} 21^{\prime} 10^{\prime \prime} \mathrm{S}, 040^{\circ}$ 04'23"W; 647 m depth; 3 Jan. 2011; Bruna Pagliani leg.; NPM 550 • 2 o (219-384 mm TL); state of Rio de Janeiro, off Macaé; 2246'55"S, 040³8'23"W, 387-393 m depth; 11 Apr. 2008; RV Gyre, Michael M. Mincarone and cruise staff leg.; bottom trawl; NPM $861 \cdot 1 \delta$ (damaged); state of Rio de Janeiro, off Macaé, 5 Jun. 2017; anonymous leg.; NPM $4519 \cdot 1$ ○े (468 mm TL); state of Rio de Janeiro, off Quissamã; 30-60 m depth; 21 Jun. 2016; anonymous leg.; gillnet; NPM 4545.

Identification. According to Soares et al. (2016), S. cabofriensis can be distinguished from all western South Atlantic congeners by its color pattern composed of randomly and asymmetrically distributed black and white spots of varied sizes (but predominantly small) (vs spots predominantly within saddles and with approximate bilateral symmetry in S. haeckelii and S. ugoi); saddles not well defined and without sharp median projections (vs well-defined saddles in S. haeckelii and saddles with sharp median projections in $S$. ugoi); claspers with a well-developed groove on the terminal portion of the ventral terminal cartilage (vs lacking groove or an undeveloped groove in S. haeckelii and S. ugoi); envelope absent and exorhipidion poorly developed (vs envelope present and exorhipidion developed in S. haeckelii); and neurocranium with a proportionately broader basal plate (vs narrow basal plate in $S$. haeckelii and in S. ugoi). In addition, an extensive list of combination of characters is provided by Soares et al. (2016). Morphometric data of the specimens examined (except the damaged specimen NPM 4519) are provided in Table 1.

\section{Scyliorhinus ugoi Soares, Gadig \& Gomes, 2015}

Figures 1, 4, Table 1

New records. BRAZIL • 1 + $(490 \mathrm{~mm}$ TL); state of Santa Catarina, off Cabo de Santa Marta; 825 m depth; 3 Mar. 2001; FV Saga de Thor, anonymous leg.; bottom trawl; LEAP 157.

Identification. According to Soares et al. (2016), S. ugoi can be distinguished from western South Atlantic congeners by its color pattern composed by spots predominantly within saddles and with approximate bilateral symmetry (vs randomly and asymmetrically distributed black and white spots of varied sizes, but predominantly small, in S. cabofriensis); saddles with sharp median projections (vs saddles not well defined and without sharp

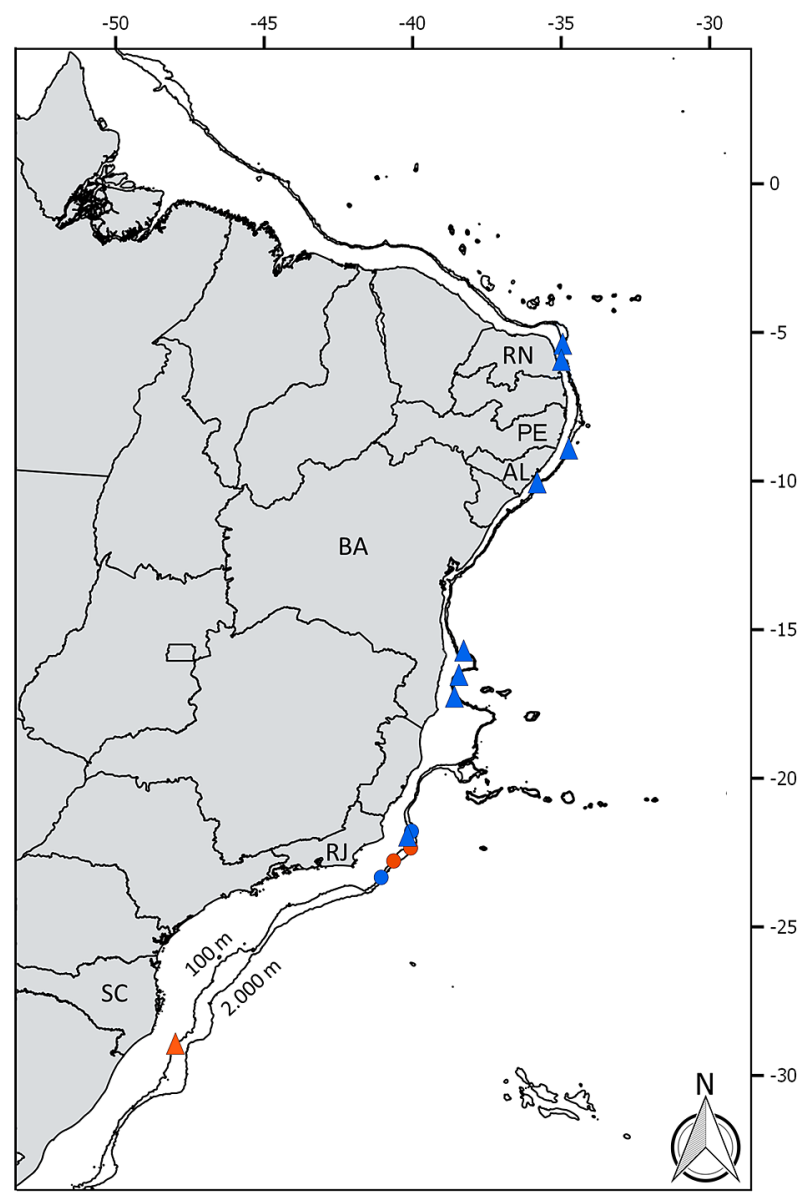

Figure 1. Records of Scyliorhinus cabofriensis (circles) and S. ugoi (triangles) along the Brazilian coast. Blue symbols are records from literature and red symbols represent new records. Selected Brazilian states: $\mathrm{RN}=$ Rio Grande do Norte; $\mathrm{PE}=$ Pernambuco; $\mathrm{AL}=$ Alagoas; $\mathrm{BA}=$ Bahia; $\mathrm{RJ}=$ Rio de Janeiro; $\mathrm{SC}=$ Santa Catarina. 


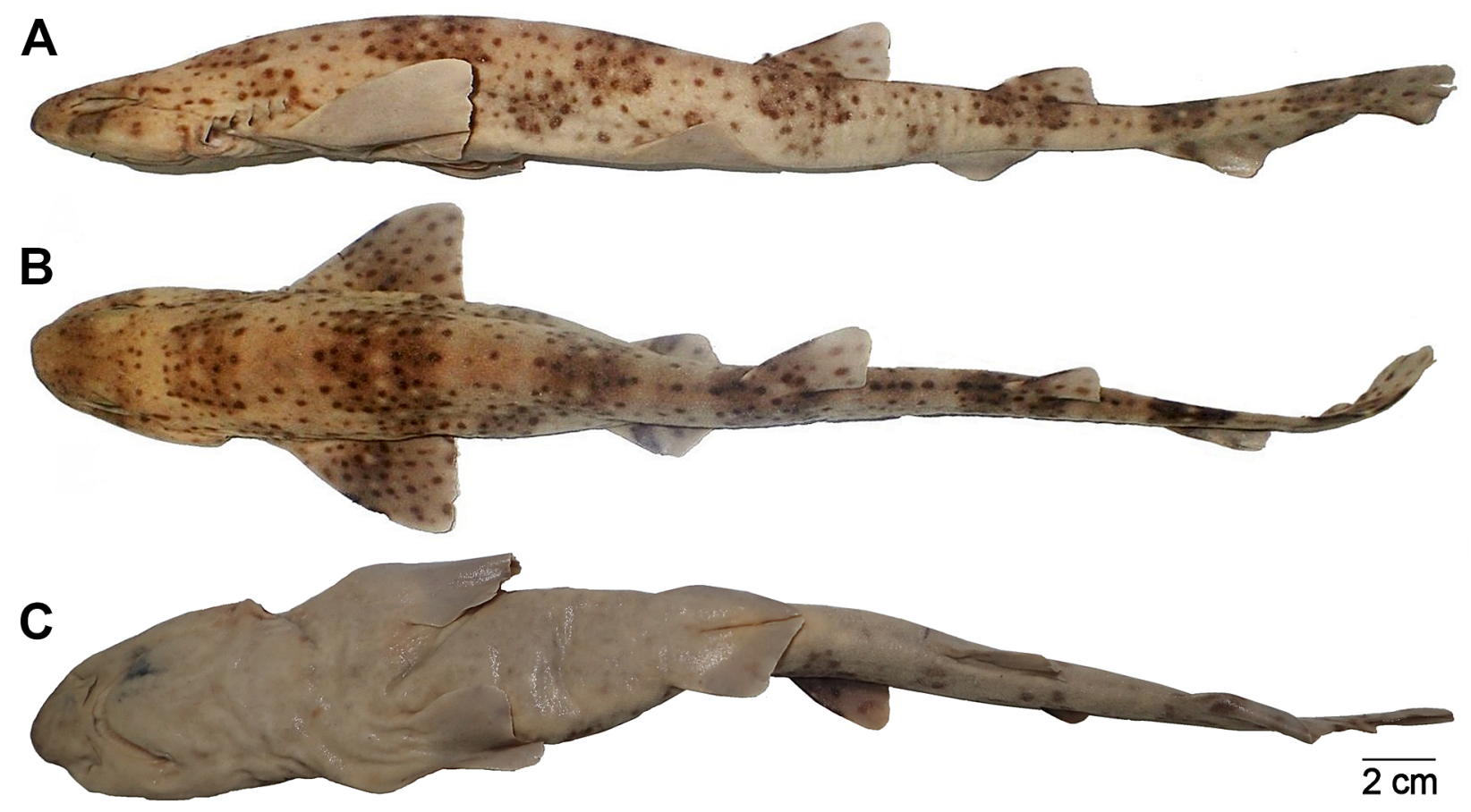

Figure 2. Scyliorhinus cabofriensis, NPM 861 (female, $384 \mathrm{~mm}$ TL), collected off Macaé, RJ, Brazil. A. Lateral view. B. Dorsal view. C. Ventral view.

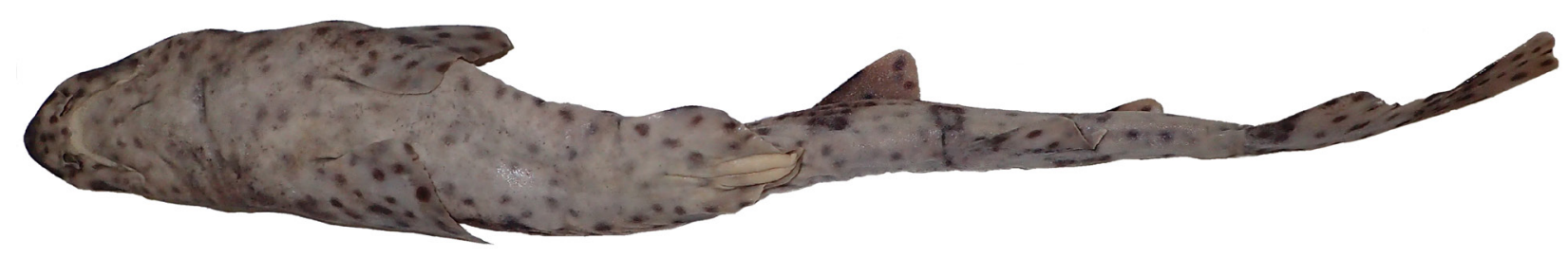

Figure 3. Ventral view of Scyliorhinus cabofriensis, NPM 4545 (male, 468 mm TL), collected off Quissamã, RJ, Brazil.

median projections in S. cabofriensis and well-defined saddles in S. haeckelii); clasper lacking groove or an undeveloped groove (vs claspers with a well-developed groove on the terminal portion of the ventral terminal cartilage in S. cabofriensis); neurocranium with a proportionately narrow basal plate (vs broader basal plate in S. ugoi). In addition, an extensive list of combination of characters is provided by Soares et al. $(2015,2016)$. Morphometric data are given in Table 1.

\section{Discussion}

Scyliorhinus cabofriensis was previously known from 23 specimens collected off northeastern Rio de Janeiro (Soares et al. 2016). All specimens were generally reported off state of Rio de Janeiro (RJ) or off Cabo Frio (type locality), without indication of coordinates and depths. The only known specimen of $S$. cabofriensis with precise collection data (MNRJ 30196) was previously recorded by Nunan and Senna (2007) as Scyliorhinus sp., which was collected by the RV Thalassa at $21^{\circ}$ $48^{\prime} 29.8^{\prime \prime} \mathrm{S}, 040^{\circ} 01^{\prime} 32.3^{\prime \prime} \mathrm{W}$, at a depth of $536 \mathrm{~m}$. The current study reports on the occurrence of five additional specimens of S. cabofriensis between Cabo de São Tomé and Macaé, from depths of 387-647 m.
Scyliorhinus ugoi was originally described based on 10 specimens collected between the states of Rio Grande do Norte and Bahia, without mention the depth range (Soares et al. 2015). A recent taxonomic review based on 26 specimens examined, revealed that $S$. ugoi occurs from Barbados (Caribbean Sea) to Rio de Janeiro (Brazil) (Soares and Carvalho 2019). The current study extends the distribution of this species to southern Santa Catarina, Brazil, based on a single specimen bottom trawled off Cabo de Santa Marta, at $825 \mathrm{~m}$ depth.

In spite of the new records, both $S$. cabofriensis and S. ugoi probably have a wider distribution when compared with those reported herein and in the literature. At the moment, whereas the distribution of $S$. ugoi extends from Barbados (Caribbean Sea) to Santa Catarina (Brazil), records of $S$. cabofriensis are restricted to state of Rio de Janeiro, from Cabo de São Tomé to Cabo Frio.

Morphometric data of all examined specimens are given in Table 1, including 18 measurements not presented in the original descriptions of $S$. cabofriensis and $S$. ugoi, which improves the description of both species. In addition, measurements of the new specimens recorded herein increase the morphometric ranges previously known for $S$. cabofriensis and $S$. ugoi, which 
Table 1. Measurements (according to Compagno 2001) for specimens of Scyliorhinus cabofriensis and Scyliorhinus ugoi examined in the current study, compared with data from the literature (ranges different from those reported in the original descriptions are indicated in bold).

\begin{tabular}{|c|c|c|c|c|c|}
\hline \multirow{2}{*}{$\begin{array}{l}\text { Species } \\
\text { Reference }\end{array}$} & \multicolumn{3}{|c|}{ Scyliorhinus cabofriensis } & \multicolumn{2}{|c|}{ Scyliorhinus ugoi } \\
\hline & Soares et al. (2016) & Current study & Current study & Soares et al. (2015) & Current study \\
\hline Sex & Males/females & Female & Male & Males/females & Female \\
\hline$n$ & 23 & 3 & 1 & 10 & 1 \\
\hline Total vertebrae & $120-124$ & $118-123$ & - & $119-135$ & - \\
\hline Total length mm (TL) & $281-468$ & 219-408 & 469 & $415-600$ & 490 \\
\hline \multicolumn{6}{|l|}{ Measurements in \% of TL } \\
\hline Precaudal length (PRC) & $76.2-79.6$ & $76.7-77.2$ & 78.5 & $74.7-76.8$ & 75.1 \\
\hline Prenarial length (PRN) & - & $4.6-4.7$ & 4.1 & - & - \\
\hline Preoral length (POR) & $4.6-5.7$ & $4.7-5.3$ & 4.4 & $4.3-5.6$ & 4.3 \\
\hline Preorbital length (POB) & $6.1-7.2$ & $4.8-6.4$ & 6.1 & $6.4-6.4$ & - \\
\hline Prespiracular length (PSP) & $11.0-11.2$ & $10.7-11.5$ & 10.9 & $10.4-10.7$ & - \\
\hline Prebranchial length (PG1) & $14.7-15.7$ & $15.8-16.2$ & 16.7 & $14.5-15.2$ & - \\
\hline Head length (HDL) & $19.7-20.8$ & $20.1-20.2$ & 20.9 & $19.5-20.3$ & - \\
\hline Prepectoral length (PP1) & $18.3-19.1$ & $18.5-19.4$ & 19.3 & $17.9-17.9$ & - \\
\hline Prepelvic length (PP2) & $40.6-42.4$ & $38.1-39.9$ & 40.9 & $41.0-43.4$ & 42.9 \\
\hline Snout-vent length (SVL) & $42.8-44.1$ & $40.2-42.9$ & 43.5 & $43.6-45.4$ & - \\
\hline Preanal length (PAL) & $51.8-61.7$ & $57.6-58.1$ & 61.8 & $59.1-64.4$ & - \\
\hline Pre-first dorsal length (PD1) & $48.9-50.6$ & $46.6-47.4$ & 52.2 & $48.4-51.2$ & - \\
\hline Pre-second dorsal length (PD2) & - & $63.8-64.0$ & 68.9 & - & - \\
\hline Interdorsal space (IDS) & $10.0-12.3$ & $10.3-11.4$ & 11.3 & $10.9-11.0$ & 10.8 \\
\hline Dorsal-caudal space (DCS) & $4.3-6.2$ & $5.7-6.7$ & 6.6 & $4.2-5.1$ & 4.7 \\
\hline Pectoral pelvic space (PPS) & $16.5-18.8$ & $16.0-16.5$ & 16.4 & $17.6-20.1$ & 18.4 \\
\hline Pelvic-anal space (PAS) & $10.8-14.3$ & $11.3-11.9$ & 15.1 & $10.5-12.8$ & 10.2 \\
\hline Anal-caudal space (ACS) & $7.2-11.5$ & $8.1-8.8$ & 8.6 & $7.4-7.6$ & 7.3 \\
\hline Eye length (EYL) & $3.6-4.4$ & $4.5-4.8$ & 4.7 & $3.8-4.0$ & 4.3 \\
\hline Interorbital space (INO) & $6.8-7.2$ & $6.7-7.3$ & 6.2 & $6.1-6.6$ & 6.5 \\
\hline Nostril width (NOW) & - & $7.1-7.9$ & 5.8 & - & 2.6 \\
\hline Internarial space (INW) & $1.8-2.7$ & $1.7-2.0$ & 1.9 & $1.4-2.4$ & 2.2 \\
\hline Anterior nasal flap length (ANF) & - & $1.9-2.1$ & 1.0 & - & 1.6 \\
\hline Spiracle length (SPL) & - & $0.6-0.9$ & 0.7 & - & 0.7 \\
\hline Distance between spiracles (DBS) & - & $8.2-8.6$ & 7.9 & - & 8.6 \\
\hline Mouth length (MOL) & $3.6-7.2$ & $3.7-3.9$ & 3.6 & $3.7-5.1$ & 3.3 \\
\hline Mouth width (MOW) & $7.4-8.2$ & 7.1-7.5 & 6.2 & $9.0-9.7$ & 8.4 \\
\hline Lower labial furrow length (LLA) & $1.8-2.3$ & $1.1-1.6$ & 1.4 & $1.9-2.1$ & 2.2 \\
\hline First gill slit height (GS1) & $1.8-3.1$ & $1.7-2.0$ & 1.5 & $2.8-3.1$ & - \\
\hline Second gill slit height (GS2) & - & $1.5-1.9$ & 1.3 & - & - \\
\hline Third gill slit height (GS3) & - & $1.2-1.7$ & 1.5 & - & - \\
\hline Fourth gill slit height (GS4) & - & $1.0-1.5$ & 1.4 & - & - \\
\hline Fifth gill slit height (GS5) & $1.0-1.7$ & $\mathbf{0 . 8 - 1 . 1}$ & 0.9 & $0.9-1.8$ & 1.0 \\
\hline Head height (HDH) & $7.2-7.5$ & $7.1-8.6$ & 8.5 & $5.4-6.6$ & 8.8 \\
\hline Head width (HDW) & $12.3-12.9$ & $\mathbf{1 0 . 6}-12.3$ & 11.5 & $13.0-13.3$ & 12.8 \\
\hline Trunk height (TRH) & - & $8.6-10.3$ & 8.9 & $9.5-12.2$ & 9.3 \\
\hline Trunk width (TRW) & - & $9.5-11.1$ & 9.3 & $10.9-14.5$ & 11.0 \\
\hline Tail height (TAH) & - & $4.1-7.8$ & 6.7 & - & 6.7 \\
\hline Tail width (TAW) & - & $2.9-5.0$ & 4.5 & - & 5.1 \\
\hline Caudal peduncle height (CPH) & $3.6-3.6$ & $3.0-3.5$ & 3.2 & $3.1-3.3$ & 2.8 \\
\hline Caudal peduncle width (CPW) & $2.7-3.2$ & $2.2-2.3$ & 2.9 & $1.9-2.3$ & 2.2 \\
\hline Pectoral length (P1L) & $10.4-12.3$ & $12.5-13.8$ & 11.3 & $12.8-13.6$ & 12.6 \\
\hline Pectoral anterior margin (P1A) & $11.8-13.3$ & $13.4-14.3$ & 13.0 & $14.5-15.0$ & 14.4 \\
\hline Pectoral base (P1B) & $6.1-7.8$ & $5.6-6.7$ & 5.7 & $3.1-7.2$ & 6.3 \\
\hline Pectoral inner margin (P1I) & $6.1-6.5$ & $4.7-6.2$ & 5.3 & $5.9-7.1$ & 6.5 \\
\hline Pectoral posterior margin (P1P) & $7.4-9.1$ & $8.3-9.4$ & 9.5 & $8.7-9.0$ & 10.6 \\
\hline Pelvic length (P2L) & $10.0-11.4$ & $9.6-10.5$ & 11.4 & $9.0-10.5$ & 10.2 \\
\hline Pelvic anterior margin (P2A) & $6.1-7.2$ & $5.6-6.1$ & 6.3 & $6.6-7.4$ & 6.9 \\
\hline Pelvic base (P2B) & $6.1-6.8$ & $6.4-7.3$ & 6.7 & $6.4-8.9$ & 6.7 \\
\hline Pelvic height (P2H) & - & $2.4-3.2$ & 4.4 & - & 4.4 \\
\hline Pelvic inner margin (P2l) & $3.6-5.5$ & $2.8-3.1$ & 5.7 & $3.1-3.8$ & 3.2 \\
\hline Pelvic posterior margin (P2P) & $5.4-7.6$ & $4.7-6.1$ & 7.5 & $6.4-6.6$ & 6.5 \\
\hline Clasper outer length (CLO) & $3.2-4.8$ & - & 5.1 & $3.8-4.1$ & - \\
\hline Clasper inner length (CLI) & $9.3-10.4$ & - & 8.2 & $8.1-9.0$ & - \\
\hline
\end{tabular}


Table 1. Continued.

\begin{tabular}{|c|c|c|c|c|c|}
\hline \multirow{2}{*}{$\begin{array}{l}\text { Species } \\
\text { Reference }\end{array}$} & \multicolumn{3}{|c|}{ Scyliorhinus cabofriensis } & \multicolumn{2}{|c|}{ Scyliorhinus ugoi } \\
\hline & Soares et al. (2016) & Current study & Current study & Soares et al. (2015) & Current study \\
\hline Clasper base width (CLB) & $1.0-1.4$ & - & 1.2 & $0.4-0.8$ & - \\
\hline First dorsal length (D1L) & - & $9.6-10.7$ & 9.8 & - & 9.3 \\
\hline First dorsal anterior margin (D1A) & $9.9-10.0$ & $8.9-11.6$ & 10.0 & $9.7-10.0$ & 10.8 \\
\hline First dorsal base (D1B) & $5.7-6.5$ & $5.4-6.1$ & 6.8 & $6.6-7.1$ & 6.5 \\
\hline First dorsal height (D1H) & $4.3-5.7$ & $4.9-5.8$ & 4.9 & $5.7-5.9$ & 5.9 \\
\hline First dorsal inner margin (D1I) & $2.8-4.2$ & $3.2-3.8$ & 3.2 & $3.1-3.4$ & 2.8 \\
\hline First dorsal posterior margin (D1P) & - & $4.5-7.7$ & 4.7 & - & 5.9 \\
\hline Second dorsal length (D2L) & - & $8.2-8.5$ & 8.3 & - & 7.9 \\
\hline Second dorsal anterior margin (D2A) & $7.6-8.2$ & $7.6-8.6$ & 7.8 & $5.0-7.6$ & 8.1 \\
\hline Second dorsal base (D2B) & $5.4-6.5$ & $5.6-5.7$ & 5.4 & $5.5-6.1$ & 5.3 \\
\hline Second dorsal height (D2H) & $3.2-3.8$ & $3.1-4.1$ & 3.5 & $3.8-4.7$ & 3.4 \\
\hline Second dorsal inner margin (D2I) & $2.1-2.7$ & $2.5-3.0$ & 2.8 & $2.6-2.9$ & 2.6 \\
\hline Second dorsal posterior margin (D2P) & - & $2.9-3.3$ & 3.4 & - & 3.4 \\
\hline Anal length (ANL) & - & $10.8-13.2$ & 10.2 & - & 11 \\
\hline Anal anterior margin (ANA) & $7.8-7.9$ & $7.7-9.2$ & 7.7 & $8.3-8.7$ & 8.5 \\
\hline Anal base (ANB) & $7.9-9.1$ & $8.1-9.8$ & 7.8 & $5.7-7.7$ & 8.5 \\
\hline Anal height (ANH) & $3.6-4.4$ & $2.8-4.8$ & 4.0 & $4.2-4.6$ & 4.7 \\
\hline Anal inner margin (ANI) & $2.1-3.4$ & $2.0-2.6$ & 3.0 & $2.6-2.9$ & 2.8 \\
\hline Anal posterior margin (ANP) & $4.3-5.5$ & $4.3-6.3$ & 4.9 & $5.1-5.4$ & 5.7 \\
\hline Dorsal caudal margin (CDM) & $21.6-23.0$ & $21.0-23.5$ & 21.4 & $23.4-25.3$ & 24.3 \\
\hline Preventral caudal margin (CPV) & - & $8.6-9.9$ & 9.7 & - & 11.0 \\
\hline Postventral caudal margin (CPU) & $9.6-10.5$ & $8.3-9.7$ & 7.7 & $9.4-10.7$ & 11.6 \\
\hline Subterminal caudal margin (CST) & $8.2-10.4$ & $4.9-6.8$ & 5.2 & $8.8-10.7$ & 5.7 \\
\hline Terminal caudal margin (CTR) & $5.0-5.3$ & $4.7-5.2$ & 4.7 & $5.2-5.4$ & 5.5 \\
\hline Terminal caudal lobe (CTRL) & $4.6-5.9$ & $6.4-8.0$ & 6.9 & $5.4-6.4$ & 7.3 \\
\hline
\end{tabular}

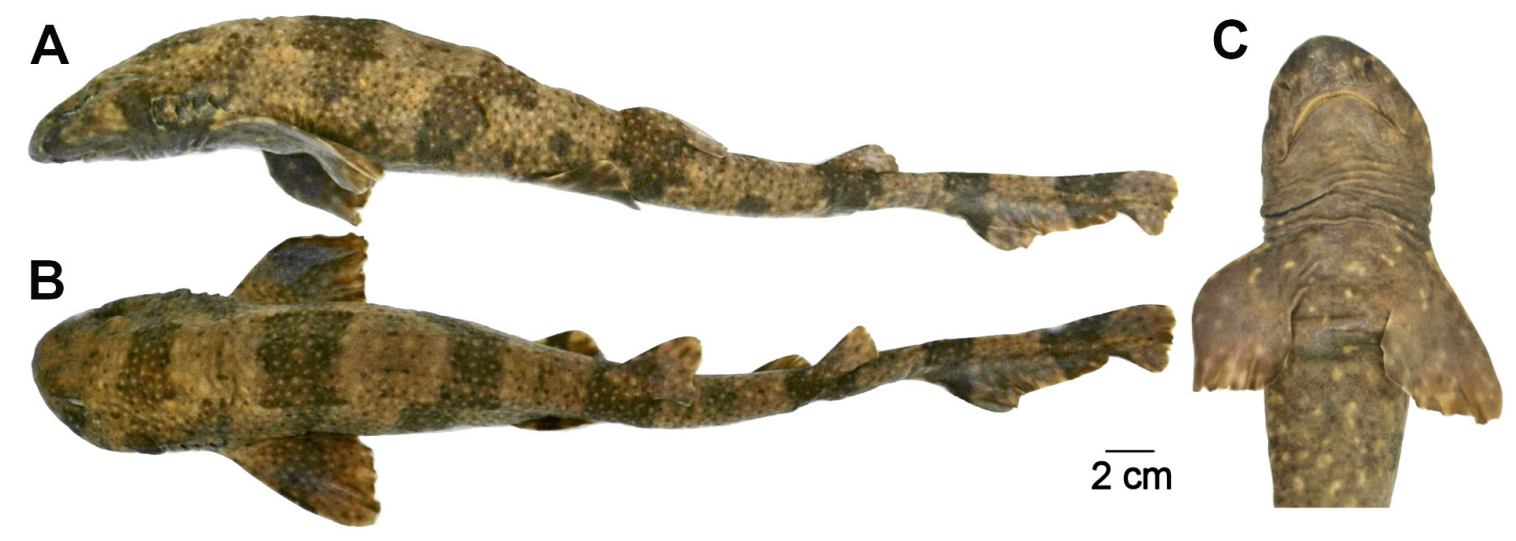

Figure 4. Scyliorhinus ugoi, LEAP 157 (female, $490 \mathrm{~mm}$ TL), collected off Cabo de Santa Marta, SC, Brazil. A. Lateral view. B. Dorsal view. C. Ventral view.

is likely to occur for species with so few specimens examined.

Among all specimens of $S$. cabofriensis, the NPM 4545 (Fig. 3) stands out by having dark spots on the ventral region of the body, a color pattern not reported in the specimens examined by Soares et al. (2016). As only 28 specimens were reported so far, the frequency in which this color pattern occurs in the population or whether this represents an anomalous coloration remain unknown.

\section{Acknowledgements}

We thank B. Pagliani, F. Di Dario, artisanal fisherman, and the crew of RV Gyre and FV Saga de Thor, for collecting and preserving the specimens examined. We also thank A. Bauer, G. Lima, M. Xavier, and T. Sarinho for lab assistance. This study is part of the final paper developed by the first author to obtain the bachelor degree in Biological Sciences at the Universidade Federal do Rio de Janeiro. We are especially grateful to the examination board, Dr Ana Cristina Petry and Dr Fabio Di Dario (UFRJ), and anonymous referees, for offering valuable suggestions. The NPM Fish Collection has been supported by the project MULTIPESCA (FUNBIO) under the grant "Pesquisa Marinha e Pesqueira", contract $104 / 2016$.

\section{Authors' Contributions}

SML, RCM and MMM performed the measurements, SML and LGF designed the figures. SML, LGF, and MMM wrote, revised, and corrected the manuscript. 


\section{References}

Compagno LJV (1984) FAO species catalogue. Vol. 4. Sharks of the world. An annotated and illustrated catalogue of shark species known to date. Part 2. Charcharhiniformes. FAO Fisheries Synopsis No. 125, 4 (2): 251-655.

Compagno LJV (2001) Sharks of the world. An annotated and illustrated catalogue of shark species known to date. Volume 2. Bullhead, mackerel and carpet sharks (Heterodontiformes, Lamniformes and Orectolobiformes). FAO Species Catalogue for Fishery Purposes 1 (2): 1-269.

Lins-Oliveira JE, Nóbrega MF, Garcia Júnior J, Sampaio CLS, Di Dario F, Fischer LG, Mincarone, MM (2015) Biodiversidade marinha da Bacia Potiguar/RN: Peixes do talude continental. Museu Nacional, Rio de Janeiro, 218 pp.

Nelson JS, Grande T, Wilson MVH (2016) Fishes of the world. 5th edition. John Wiley \& Sons, Hoboken, 707 pp.

Nunan GW, Senna MLV (2007) Tubarões (Selachii) coletados pelo navio oceanográfico Thalassa sobre a plataforma externa e talude continental do Brasil entre $11^{\circ}$ e $22^{\circ} \mathrm{S}$. In: Costa PAS, Olavo G, Martins AS (Eds.) Biodiversidade da fauna marinha profunda na costa central brasileira. Museu Nacional, Rio de Janeiro, 163-183.
Rincón-Filho G, Mazzoleni RC, Palmeira ARO, Lessa R (2017) Deepwater sharks, rays, and chimaeras of Brazil. In: Rodrigues-Filho LF (Ed.) Chondrichthyes: multidisciplinary approach. Intech Open, London, 83-112. http://doi.org/10.5772/intechopen.69471

Soares KDA, Carvalho MR (2019) The catshark genus Scyliorhinus (Chondrichthyes: Carcharhiniformes: Scyliorhinidae): taxonomy, morphology and distribution. Zootaxa 4601 (1): 1-147. http://doi. org/10.11646/zootaxa.4601.1.1

Soares KDA, Gadig OFB, Gomes UL (2015) Scyliorhinus ugoi, a new species of catshark from Brasil (Chondrichthyes: Carcharhiniformes: Scyliorhinidae). Zootaxa 3937 (2): 347-361. http://doi.org/ 10.11646/zootaxa.3937.2.6

Soares KDA, Gomes UL, Carvalho MR (2016) Taxonomic review of catsharks of the Scyliorhinus heackelii group, with the description of a new species (Chondrichthyes: Carcharhiniformes: Scyliorhinidae). Zootaxa 4066 (5): 501-534. http://doi.org/10.11646/zoo taxa.4066.5.1

Weigmann S (2016) Annotated checklist of the living sharks, batoids and chimaeras (Chondrichthyes) of the world, with a focus on biogeographical diversity. Journal of Fish Biology 88: 837-1037. https://doi.org/10.1111/jfb.12874 